\title{
MULTI-LINK LEISURE DEVELOPMENTS LTD V NORTH LANARKSHIRE COUNCIL: COMMERCIAL INTERPRETATION OR RELIEF FROM A BAD BARGAIN?
}

\author{
Adèle Taylor*
}

In the 2011 decision Multi-Link Leisure Developments Ltd v North Lanarkshire Council, the United Kingdom Supreme Court purported to apply a business common sense approach to the interpretation of an option clause in a lease. In particular, several of the Lords identified that the one possible interpretation of the clause would lead to a "windfall" - a significant financial advantage - for the appellant. Their reasons hinged significantly on their view that this was a consequence inconsistent with commercial sense, which the parties were unlikely to have intended. This article analyses the relevance of a "windfall" in the context of the modern common sense approach to the construction of contracts. It concludes that the Court's reliance upon a "windfall" of this kind goes beyond the bounds of commercial interpretation and introduces problematic notions of substantive fairness into a business common sense approach to the interpretation of contracts.

\section{INTRODUCTION}

The interpretation and construction of contracts has been described as the "staple diet" of the courts and commercial lawyers and "the very lifeblood of commercial law". ${ }^{1}$ Commercial agreements, Sir Christopher Staughton points out, are "virtually the only contracts which in these days anyone can afford to litigate about". ${ }^{2}$ However, the frequency with which these cases come

* Submitted as part of the LLB(Hons) programme at Victoria University of Wellington. I would like to thank Professor David McLauchlan for his helpful comments.

1 Robert Goff "Commercial Contracts and the Commercial Court" [1984] LMCLQ 382 at 385; Richard Calnan "Construction of Commercial Contracts: A Practitioner's Perspective" in Andrew Burrows and Edwin Peel (eds) Contract Terms (Oxford University Press, Oxford, 2007) 17 at 17.

2 Christopher Staughton "How Do the Courts Interpret Commercial Contracts?" (1999) 58 Cambridge LJ 303 at 303. 
before the courts does not mean they are run of the mill. They are often of enormous significance to the parties - that is why they have pursued litigation, in many cases to the highest appellate courts. The principles that guide judicial resolution of these commercial disputes therefore assume great practical significance. $^{3}$

A key feature of the modern approach to these cases is a shift towards the "commercial interpretation" of contracts. ${ }^{4}$ While the need to take an approach to interpretation that is in touch with business common sense is undeniable, the benefits and dangers of the role it plays have not been considered in any great depth. The recent decision of the United Kingdom Supreme Court in Multi-Link Leisure Developments Ltd v North Lanarkshire Council, ${ }^{5}$ a case of exactly the kind described above, provides a convenient landscape within which to consider the proper scope of this commercial approach.

\section{THE MULTI-LINK CASE}

\section{A Facts}

Multi-Link Leisure Developments Ltd (Multi-Link) were tenants under a lease, granted by the North Lanarkshire Council (the Council), of land located about a mile from the town of Cumbernauld, in Scotland. It was a lease for 50 years from the date of entry, which was 1 June 1999. The land had previously only been used for agricultural purposes.

Clause 9 of the lease imposed upon Multi-Link the obligation:

... to occupy and use the subjects for the development of a pay and play golf course and ancillary activities incidental to that use, and for no other purpose whatever without the prior express written consent of the landlords.

The golf course was to be developed within five years or the lease would terminate with immediate effect. Multi-Link duly developed a pay and play golf course.

Clause 18.1 gave the tenants an option to purchase the land. If exercised more than a year after the date of entry, the option price was to be determined by the landlord in accordance with the formula in cl 18.2:

The option price, if the option to purchase is exercised subsequent to the first year of let, shall be equal to the full market value of the subjects hereby let as at the date of entry for the proposed purchase (as determined by the landlords) of agricultural land or open space suitable for development as a golf

3 Ewan McKendrick Contract Law: Text, Cases and Materials (4th ed, Oxford University Press, Oxford, 2010) at 375; Mindy Chen-Wishart Contract Law (Oxford University Press, Oxford, 2010) at 440.

$4 \quad$ Mannai Investment Co Ltd v Eagle Star Life Assurance Co Ltd [1997] AC 749 (HL) at 770.

$5 \quad$ Multi-Link Leisure Developments Ltd v North Lanarkshire Council [2010] UKSC 47, [2010] 1 All ER 179 [Multi-Link Leisure Developments Ltd v North Lanarkshire Council (UKSC)]. 
course, but, for the avoidance of doubt, shall be not less than the sum of ONE HUNDRED AND THIRTY THOUSAND POUNDS $(£ 130,000)$ STERLING. In determining the full market value (i) the landlords shall assume (a) that the subjects hereby let are in good and substantial order and repair and that all obligations of the landlords and the tenants under the lease have been complied with, and (b) that the subjects hereby let are ready for occupation, and (ii) the landlords shall disregard (a) any improvements carried out by the tenants during the period of this lease otherwise than in pursuance of an obligation [to] the landlords, and (b) any damage to or destruction of the subjects hereby let.

The considerations specified in cl 18.2(i)(a) and (b) of the last sentence were commonly referred to as the "assumptions", and those in cl 18.2(ii)(a) and (b) as the "disregards".

In October 2007, Multi-Link gave written notice of their intention to exercise the option, with a proposed date of purchase in October of the following year. It was not until November 2008 that the Council accepted that the letter was a valid exercise of the option. They advised Multi-Link that the full market value of the land was $£ 5.3$ million. This price included the land's substantial hope value - the value attributable to its potential for residential development. The area within which the land was located had recently been identified in local planning documents as suitable for housing-led urban expansion. This was the first time the prospect was raised that the land might have some development value other than as a golf course.

Multi-Link disputed the basis of this valuation and asserted that £500,000 was the full market value for the purpose of the option clause, which was consistent with indications from the Council before the hope value had arisen. When the tenants failed to complete the purchase, the landlords purported to rescind both the option contract in cl 18 and the purchase contract resulting from MultiLink's notice of October 2007.

\section{$B$ Issue and Arguments}

Multi-Link sought a declaration that their option to purchase had not been validly rescinded because the landlords had based their valuation upon a wrong interpretation of cl 18.2. The case therefore turned upon the correct construction of that clause and whether: ${ }^{6}$

... in determining the option price to be paid by [Multi-Link], the [Council] were entitled to take into account inter alia the development potential of land; or whether the terms of that clause required them to assess the market value of the land for use only as a golf course.

The Council contended that it would be unreasonable if they could not have regard to the land's potential for residential development in determining the option price. Clause 18.2 did not prevent them from doing so. ${ }^{7}$ The problematic phrase "of agricultural land or open space suitable for

$6 \quad$ Multi-Link Leisure Developments Ltd v North Lanarkshire Council [2009] CSOH 114, 2009 SLT 1170 at [4] [Multi-Link Leisure Developments Ltd v North Lanarkshire Council (OH)].

$7 \quad$ Multi-Link Leisure Developments Ltd v North Lanarkshire Council (UKSC), above n 5, at [8]. 
development as a golf course" was insufficiently clear to exclude from the valuation any factors potentially relevant to the full market value; it was only a description of the physical state of the land upon which valuation was to proceed. ${ }^{8}$

Multi-Link argued that on the proper construction of cl 18.2 the words "agricultural land or open space suitable for development as a golf course" indicated the valuation was to proceed on the basis that the land was to be used as golf course and nothing else. ${ }^{9}$ In the United Kingdom Supreme Court, their primary submission was that the option price was the value of the land as undeveloped and without reference to any hope value. ${ }^{10}$ Their alternative contention was that the option price was the value of the land with the golf course constructed, but excluding any hope value. ${ }^{11}$

The parties agreed that if the Council was entitled to take into account the land's hope value, the contract to purchase the subjects was validly rescinded and the option was spent. ${ }^{12}$ Conversely, if the landlords were not so entitled, the contract to purchase the land would remain in force and the price would need to be determined afresh, in accordance with the proper interpretation of cl 18.2. ${ }^{13}$

8 Multi-Link Leisure Developments Ltd v North Lanarkshire Council (OH), above n 6, at [7]; Multi-Link Leisure Developments Ltd v North Lanarkshire Council [2009] CSIH 96, 2010 SC 302 (IH (E Div)) at [17] [Multi-Link Leisure Developments Ltd v North Lanarkshire Council (IH (E Div))]; Multi-Link Leisure Developments Ltd v North Lanarkshire Council (UKSC), above n 5, at [1].

$9 \quad$ Multi-Link Leisure Developments Ltd v North Lanarkshire Council (IH (E Div)), ibid at [3]; Multi-Link Leisure Developments Ltd v North Lanarkshire Council (UKSC), above n 5, at [1], [36] and [40].

10 Multi-Link Leisure Developments Ltd v North Lanarkshire Council (UKSC), above n 5, at [10] and [40]. This stance is puzzling because to accept that the assumptions and disregards provided the description of the state in which the subjects were to be valued (as developed) would support Multi-Link's case: it would suggest that the earlier phrase "of agricultural land or open space suitable for development as a golf course" could not be an inconsistent description. Therefore it must have some other meaning and, as Lord Glennie found, that meaning could be that it limited the uses to which the valuer could have regard.

11 At [40].

12 Multi-Link Leisure Developments Ltd v North Lanarkshire Council (IH (E Div)), above n 8, at [10]; MultiLink Leisure Developments Ltd v North Lanarkshire Council (UKSC), above n 5, at [2].

13 Multi-Link Leisure Developments Ltd v North Lanarkshire Council (OH), above n 6, at [4]; Multi-Link Leisure Developments Ltd v North Lanarkshire Council (IH (E Div)), above n 8, at [9]; Multi-Link Leisure Developments Ltd v North Lanarkshire Council (UKSC), above n 5, at [2]. 


\section{B Decision of the Outer House}

At first instance, Lord Glennie considered that certain parts of cl 18.2 could safely be disregarded in order to resolve the issue. As well as the assumptions and disregards, the essentials of the clause were: ${ }^{14}$

The Option Price ... shall be equal to the full market value of the subjects hereby let ... for the proposed

purchase ... of agricultural land or open space suitable for development as a golf course.

In his view, the reference to suitability for development as a golf course was a "clear pointer" that this was the sole use that the valuer could take into consideration. ${ }^{15}$ This was consistent with the requirement that the land only be developed as a golf course. Whilst this obligation only persisted as long as the lease endured, it suggested that the parties had contemplated it was this use to which the land would be put in the foreseeable future. ${ }^{16}$ What else would be the purpose of inserting "of agricultural land or open space suitable for development as a golf course" if it were not to limit the uses by reference to which the land was to be valued? ${ }^{17}$ It could not be a description of the state in which the land was to be valued because that would be directly contrary to the assumptions and disregards. After five years, the first assumption required the valuer to proceed on the basis that Multi-Link had complied with their obligation to develop a golf course. ${ }^{18}$

Therefore, Lord Glennie concluded in favour of Multi-Link. Clause 18.2 required the option price to be the full market value of the land, as developed, by reference to its use only as a golf course. The valuer was not entitled to take any hope value into account. ${ }^{19}$ This conclusion reconciled the earlier parts of the clause with the assumptions and disregards. Although the Supreme Court ultimately decided this was impossible, Lord Hope let slip that he too could see how MultiLink's interpretation made sense of the different parts of $\mathrm{cl}$ 18.2. In seeking the meaning of the assumptions and disregards, he said: ${ }^{20}$

Their function is not hard to understand if the full market value is to be determined simply on the basis that the subjects are to be assumed to be agricultural land or open space suitable for development as a golf course. What they require the valuer to do is to make further assumptions which tend to indicate that he is to value the subjects strictly according to their actual state and existing use as at the date of

14 Multi-Link Leisure Developments Ltd v North Lanarkshire Council (OH), above n 6, at [5].

15 At [9].

16 Ibid.

17 Ibid.

18 Ibid.

19 At [10].

20 Multi-Link Leisure Developments Ltd v North Lanarkshire Council (UKSC), above n 5, at [17]. 
entry for the proposed purchase, disregarding tenants' improvements and any damage to or destruction of the subjects.

\section{Decision of the Inner House, Extra Division}

The Council appealed to the Inner House, Extra Division. Writing for the Court, Temporary Judge Sir David Edward QC sought the ordinary meaning of the words used. ${ }^{21}$ In his opinion, the phrase "agricultural land or open space suitable for development as a golf course" was a clear description that required the valuer to ignore any work done by Multi-Link to construct a golf course. The land was therefore to be valued as if it were undeveloped. ${ }^{22}$ In light of this conclusion, the Inner House, Extra Division concluded that "full market value" meant what it said, and considerations relevant to the land's value - such as the potential for residential development - could not be ignored in the absence of express words to that effect. ${ }^{23}$ Thus, without any reference to the assumptions and disregards, the Inner House, Extra Division decided in favour of the Council.

\section{MULTI-LINK IN THE UNITED KINGDOM SUPREME COURT}

Multi-Link appealed to the United Kingdom Supreme Court. The five judges unanimously dismissed the appeal, reaching the same outcome as the Inner House, Extra Division but for different reasons.

\section{A Lord Hope}

According to Lord Hope, the Court's task was to give the words of cl 18.2 their ordinary meaning in the contractual context unless the language created an otherwise irresolvable ambiguity. ${ }^{24}$ Despite seeing the possibility of Multi-Link's interpretation, his Lordship concluded that cl 18.2 contained an irreconcilable ambiguity: ${ }^{25}$

The assumptions and disregards are designed to settle the basis for a purchase of subjects in their existing use. The earlier parts of the clause are designed to settle the price for the purchase of subjects that will have a value in the open market that takes account of their potential for development.

He gave that meaning to the earlier parts of the clause because, in his opinion, it would make commercial sense for the option price to include any hope value: ${ }^{26}$

21 Multi-Link Leisure Developments Ltd v North Lanarkshire Council (IH (E Div)), above n 8, at [25].

22 At [26].

23 At [28]-[29].

24 Multi-Link Leisure Developments Ltd v North Lanarkshire Council (UKSC), above n 5, at [11].

25 At [19].

26 At [16]. 
... once the option is exercised all restrictions on the use of the land fly off. The tenants will become the owners of the land. They will be free to sell it on to a third party at its full market value or to use it themselves for any use whatever that will get planning permission. Both parties to the lease, if they had applied business commonsense, would have been aware of the advantages that ownership would confer on the tenant in the event of the option clause being exercised. This suggests that, if it had been their intention to restrict the option price to the value of the subjects as a golf course and to exclude any value attributable to their potential for development, they would have said so.

Having found an irresolvable ambiguity, Lord Hope sought to give a sensible and businesslike meaning to the clause as a whole, as interpreted within the factual background and with regard to the commercial object of the provision. ${ }^{27}$ Here, the relevant background included that the landlords were a local authority with a statutory duty to obtain the best consideration reasonably possible. ${ }^{28}$ Multi-Link was a commercial, profit-driven organisation. At the time the lease was entered into there was no evidence the land had any hope value other than for recreational activities, but neither were there any planning constraints inhibiting its potential for development. His final contextual consideration was that: ${ }^{29}$

If the tenants are right, acquiring the land at a price which ignores its potential for development will provide them with a very substantial windfall at the expense of the landlords. This was something that the wording of the option clause might have been expected to guard against. The tenants, on the other hand, did not ensure that the opportunity to obtain a windfall in circumstances such as have now arisen was expressly provided for.

Therefore, for essentially the same business common sense reasons that he concluded the earlier parts of the clause allowed the hope value to be considered, Lord Hope decided that this meaning was not outweighed by the assumptions and disregards. ${ }^{30}$ The meaning of the clause as a whole must be that the option price was the "full market value of the land as described, taking full account of its potential, if any, for development". ${ }^{31}$

\section{$B$ Lord Rodger and Lord Dyson}

Lord Rodger, with whom Lord Dyson agreed, described the lease as a "commercial agreement which [was] to be construed accordingly". ${ }^{32}$ Because cl 18.2 was badly drafted, his Lordship found

27 At [19].

28 At [22].

29 At [23].

30 Ibid.

31 Ibid.

32 At [26]. This is an interesting contrast with the Inner House, Extra Division's rejection of the application of commercial contract interpretation principles to this "Scottish lease of heritable property". On the latter, the 
it helpful "to start with the parts whose meaning is clear and then to use those parts to unravel the meaning of the parts which are more difficult to understand". ${ }^{33}$

He began with the assumptions and disregards which, in his opinion, clearly required the land to be valued on the basis that the golf course had indeed been developed and well maintained. ${ }^{34}$ The contractual context supported his reasoning that the cost of constructing the golf course formed part of the consideration for the lease. ${ }^{35}$ If Multi-Link wanted to buy a golf course, they would have to pay for it again. ${ }^{36}$

Since the assumptions and disregards provided the physical description of the land for the purpose of the valuation, Lord Rodger refused to construe the troubling phrase "of agricultural land or open space suitable for development as a golf course" as an inconsistent description. ${ }^{37}$ But he also rejected Multi-Link's submission that those critical words required the valuer to ignore any other factors relevant to the value of the golf course. ${ }^{38}$ His reasons for doing so were brief: ${ }^{39}$

Given that - apart from planning considerations - there is no limit on the use to which the land could be put if Multi-Link successfully exercised their option to purchase it, that would be a highly unusual and artificial approach to valuation - far less to determining "the full market value" of the land.

This conclusion was foreshadowed by his earlier observation that, in the context of a commercial venture, it was: ${ }^{40}$

... noteworthy that Multi-Link's interpretation of the disputed clause of the lease produces a result whether or not appropriately described as "a windfall" - which it seems unlikely that the parties to a commercial agreement would ever have intended: that Multi-Link should be able to buy the land for a sum that takes no account of its (substantial) hope value.

Inner House, Extra Division thought that, "The man on the Jubilee line on his way to Canary Wharf has less to say to us in this context than the Scots conveyancer with whose mindset we are more familiar": MultiLink Leisure Developments Ltd v North Lanarkshire Council (IH (E Div)), above n 8, at [24].

33 At [28].

34 At [31].

35 Ibid.

36 Ibid.

37 At [33].

38 At [34]

39 At [36].

40 At [26]. 


\section{Baroness Hale}

Baroness Hale thought the words "of agricultural land or open space suitable for development as a golf course" gave rise to a "conundrum". ${ }^{41}$ She explained that it would be ungrammatical if they were linked to "full market value", and if they referred to "proposed purchase" they would be redundant as an inaccurate description of the land. ${ }^{42}$

To solve this puzzle, Baroness Hale found comfort in Lord Rodger's approach: "construe the words you can understand and see where that takes you". ${ }^{43}$ The assumptions and disregards clearly required the valuer to assume that the tenant had complied with the obligation to build a golf course. ${ }^{44}$ The problematic words were therefore not a description of the state in which the land was to be valued, and, in her view, this "also suggest[ed] that they [were] not meant to limit the ordinary meaning of 'full market value"'. ${ }^{45}$ To this reasoning she added two further arguments: ${ }^{46}$

... if [the words] were meant to limit it, they would have come immediately after "full market value" and been preceded by "as" rather than "of". Finally, if the parties had meant anything other than the ordinary sense of "full market value" they could so easily have used a different phrase.

\section{Lord Clarke}

Lord Clarke succinctly asserted that any conclusion other than for the valuation to include hope value "would flout business common sense because it would give the tenants an unwarranted windfall". ${ }^{47}$

\section{A KEY CONCERN}

The judgments given by the United Kingdom Supreme Court are troublesome for numerous reasons: one need look no further than Lord Hope's requirement that there be a patent ambiguity before a court can have regard to the context of the agreement. Fortunately, McLauchlan has subjected the reasoning to a rigorous and insightful analysis in his paper "A Construction Conundrum?". ${ }^{48}$ However, the Multi-Link decision draws into sharp focus a more general issue.

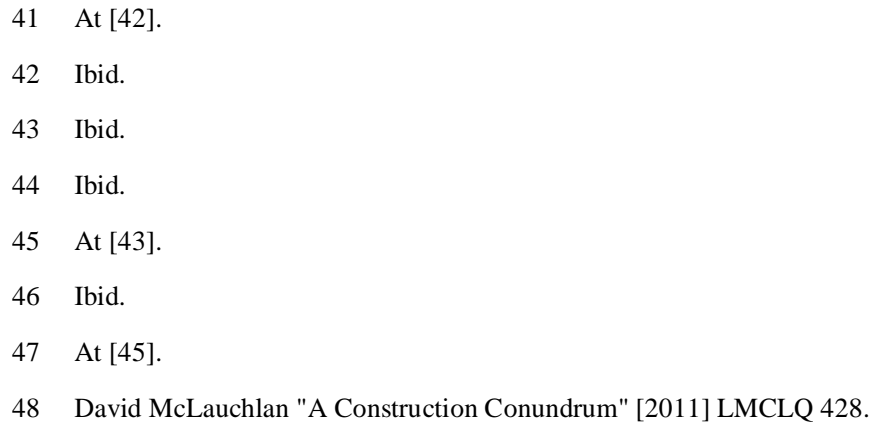


The Supreme Court gave little credence to Multi-Link's contended interpretation. They wasted no words acknowledging the plausibility of the interpretation accepted by Lord Glennie; Lord Hope stumbled across the possibility but did not pause to consider it properly. Why then did the Judges so confidently reject the tenant's interpretation? With the exception of Baroness Hale, a preponderant part of their reasoning hinged upon notions of business common sense and commercial likelihood.

Lord Hope thought that a "substantial windfall" to Multi-Link was an outcome that reasonable commercial men would not have intended. Similarly, Lord Clarke asserted that for the tenants to enjoy an "unwarranted windfall" would flout business common sense. Their Lordships used "windfall" to describe the significant financial advantage that Multi-Link would enjoy if the option price did not include the hope value of the land because, as the new owners, they could sell the land for a substantial profit, or (subject to planning permission) use it however they wished. Lords Rodger and Dyson were hesitant to apply the "windfall" label but addressed essentially the same concern: it was unlikely that parties to a commercial agreement intended that Multi-Link would be able to purchase the land for a price not including the substantial hope value.

It is true that principles of contract interpretation suggest courts should favour a commercially sensible construction, or an interpretation that complies with business common sense. ${ }^{49}$ This is because "a commercial construction is more likely to give effect to the intentions of the parties". ${ }^{50}$ The relevance of business common sense also reflects Lord Bingham's well-known philosophy that "the law should be the handmaid of commerce, not its dominatrix". ${ }^{51}$ But does this commercial approach to interpretation validate the decisive weight that these four Judges attribute to the windfall?

Multi-Link illustrates that commercial interpretation, improperly applied, can cause courts to lose sight of their fundamental interpretive task: to determine the meaning of the contract that the parties made. It is not the role of the court to substitute for the contract made a different bargain that the parties would or should have made had they acted more sensibly. ${ }^{52}$ That the Supreme Court

49 Mannai Investment Co Ltd v Eagle Star Life Assurance Co Ltd, above n 4, at 771; MP Furmston and JN Adams (eds) The Law of Contract (3rd ed, Butterworths, London, 2007) at 673.

50 Mannai Investment Co Ltd v Eagle Star Life Assurance Co Ltd, ibid at 771; Society of Lloyd's v Robinson [1999] 1 WLR 756 (HL) at 763; see also Gerard McMeel "The Rise of Commercial Construction in Contract Law" [1998] LMCLQ 382 at 383.

51 Lord Bingham of Cornhill "A New Thing Under the Sun? The Interpretation of Contract and the ICS Decision" (2008) 12 Edin LR 374 at 381.

52 See Commerzbank AG v Price-Jones [2003] EWCA Civ 1663, [2004] 1 P \& CR DG 15 at [21] per Mummery LJ; City Alliance Ltd v Oxford Forecasting Services Ltd [2000] EWCA Civ 510, [2001] 1 All ER Comm 233 at [17]; Megaro v Di Popolo Hotels Ltd [2007] EWCA Civ 309, [2007] 2 P \& CR 28 at [19]. 
moved into this impermissible territory is illustrated by the comments of Lord Hope, who preferred the Council's interpretation because it was: ${ }^{53}$

... what reasonable commercial men would have agreed to when the lease was entered into, if they had

applied their minds to the benefits that would accrue to the tenants if they were to exercise the option to

purchase. I would hold that it must be taken to be what the parties agreed to in this case.

Therefore, the Supreme Court arguably made the contract for the parties it thought was more sensible. It is a fundamental tenet of contract law that it is not the role of the court to interpret a contract to improve the bargain the parties made. ${ }^{54}$ To do so would erode certainty and sanctity of contract, ${ }^{55}$ and be fundamentally inconsistent with the key objective underlying contract law principles - to protect and give effect to the reasonable expectations of the parties. ${ }^{56}$ No effect is given to those reasonable expectations if the contract upheld is an entirely different bargain from that upon which the parties based their expectations. ${ }^{57}$

The Multi-Link case therefore highlights for discussion the scope and propriety of the role business common sense plays in contract interpretation. At what point does seeking a commercially sensible interpretation become making, for the parties, the most commercially sensible bargain? As McKendrick has aptly observed, "the line between 'commercial construction' (which is permissible) and 're-writing the contract' (which is not) is a difficult one to draw". ${ }^{58}$

\section{A COMMERCIALLY SENSIBLE APPROACH}

The trend towards commercially sensible interpretation of contracts reflects a more general movement towards common sense interpretation. In Investors Compensation Scheme Ltd $v$ West Bromwich Building Society, Lord Hoffmann prefaced his authoritative statement of contract

53 Multi-Link Leisure Developments Ltd v North Lanarkshire Council (UKSC), above n 5, at [23] (emphasis added). Similarly, Lord Clarke said at [45] (emphasis added):

I do not think that the parties can have given express consideration to the question that has arisen in this case. If they had, they would surely have expressly provided that, if the tenants exercised the option to purchase in $\mathrm{cl} 18$ of the lease, they must pay the full market value of the land as described, taking full account of its potential, if any, for development.

54 PS Davies "Interpreting Commercial Contracts: Back to the Top" (2011) 127 LQR 185 at 187.

55 See Andrew Phang "Security of Contract and the Pursuit of Fairness" (2000) 16 JCL 158.

56 Johan Steyn "Contract Law: Fulfilling the Reasonable Expectations of Honest Men" (1997) 113 LQR 433 at 434; First Energy v Hungarian International Bank [1993] 2 Lloyd's Rep 194 (CA) at 196.

57 As Alan Barron has explained, to say "one is concerned with the expectations of the contracting parties is to consider at the time the contract was concluded what the parties had in mind for its future performance": "The Rise of Legal Pragmatism in English Contract Law" (2006) 22 JCL 199 at 212.

58 Ewen McKendrick "The Interpretation of Contracts: Lord Hoffmann's Restatement" in Sarah Worthington (ed) Commercial Law and Commercial Practice (Hart Publishing, Portland, 2003) 139 at 160. 
interpretation principles with the observation that their effect was "to assimilate the way in which such documents are interpreted by judges to the common sense principles by which any serious utterance would be interpreted in ordinary life". ${ }^{59}$ The starting point is Lord Hoffmann's first principle: ${ }^{60}$

Interpretation is the ascertainment of the meaning which the document would convey to a reasonable person having all the background knowledge which would reasonably have been available to the parties in the situation in which they were at the time of the contract.

It is the meaning of the document as a whole that is sought, and it is ascertained from the standpoint of the reasonable person - or in the commercial context, the reasonable businessperson. ${ }^{61}$ The court takes a common sense rather than a pedantic approach to language, because "the reasonable commercial person can safely be assumed to be unimpressed with technical interpretations and undue emphasis on niceties of language". ${ }^{62}$

A defining feature of the modern approach is that the context of the contract is an indispensable and inseparable component of the "unitary exercise" of interpretation. ${ }^{63}$ It is relevant even where the words appear unambiguous and can enable the reasonable person interpreting the document to decide that parties have used the wrong words or syntax or otherwise not expressed themselves very well. ${ }^{64} \mathrm{~A}$ court that identifies a linguistic mistake is entitled to give effect to the meaning that the document, considered as a whole and within its context, nevertheless conveys. ${ }^{65}$ In Chartbrook Ltd $v$ Persimmon Homes Ltd, the House of Lords confirmed that a court can do so even if it "might have

59 Investors Compensation Scheme Ltd v West Bromwich Building Society [1998] 1 WLR 896 at 912-913. Lord Hoffmann's statement was adopted in New Zealand in Boat Park Ltd v Hutchison [1999] 2 NZLR 74 (CA).

60 Ibid.

61 Gerard McMeel Construction of Contracts: Interpretation, Implication and Rectification (2nd ed, Oxford University, Oxford, 2011) at 1.154; see Hombourg Houtimport BC v Agrosin Ltd (The Starsin) [2003] UKHL 12, [2004] 1 AC 715 at [10] per Lord Bingham, quoting Glynn v Margetson \& Co [1893] AC 351 (HL).

62 Society of Lloyd's v Robinson, above n 50, at 763. See also Mannai Investment Co Ltd v Eagle Assurance Co $L t d$, above $\mathrm{n} 4$, at 771 . McKendrick observes that this assumption should not be invariably applied: Ewan McKendrick Contract Law: Text, Cases and Materials, above n 3, at 389.

63 Rainy Sky SA v Kookmin Bank [2011] UKSC 50, [2011] 1 WLR 2900 at [21]; Chartbrook Ltd v Persimmon Homes Ltd [2009] UKHL 38, [2009] 1 AC 1101 at [24].

64 See Mannai Investment Co Ltd v Eagle Assurance Co Ltd, above n 4, at 774 per Lord Hoffmann. The absence of an ambiguity pre-requisite was confirmed in Starrenburg v Mortre Holdings (2004) 6 NZCPR 193 (CA) at [43] and Ansley v Prospectus Nominees Unlimited [2004] 2 NZLR 590 (CA) at [36] and [37].

65 This approach is commended by both McMeel (Gerard McMeel "The Rise of Commercial Construction in Contract Law", above n 50, at 390) and Lord Hoffmann (see Jumbo King Ltd v Faithful Properties Ltd (1999) 2 HKCFAR 279 (Hong Kong Court of Final Appeal) at [52]). 
to express that meaning in language quite different from that used by the parties", and in this respect there is no "limit to the amount of red ink or verbal arrangement or correction which the court is allowed". 66

This approach is important for ensuring that the way in which courts interpret contracts gives effect to commercial sense. Notably, it can enable a court in search of a businesslike interpretation to rewrite the language of the parties' contract. Critically, the ability of the court to do so does not, however, entitle a court to remake the parties' contract or bargain itself. This is because a court can only adapt language or syntax when it is clear what the reasonable person would have understood the document to mean - when it is plain what, objectively, the parties did agree. ${ }^{67}$ It is impermissible to rewrite the words to reflect what the court may think the parties ought to have agreed as a fairer or more commercially sensible result. ${ }^{68}$ As Rix LJ warned in Ing Bank $N V v$ Ros Roca $S A{ }^{69}$

Judges should not see in Chartbrook an open sesame for reconstructing the parties' contract, but an opportunity to remedy by construction a clear error of language which could not have been intended.

\section{PREFERRING COMMERCIALLY SENSIBLE CONSEQUENCES}

However, business common sense also plays a more specific role in governing the meaning that is given to a commercial document and it is this aspect of commercial interpretation that the United Kingdom Supreme Court relies upon in Multi-Link. A consequential analysis, evaluating the rival interpretations' consistency (or otherwise) with commercial sense, is as important as context in ascertaining the meaning of a document. ${ }^{70}$ That a court can take into account the consequences of competing interpretations is, in the words of Sir Christopher Staughton, "based on obvious common sense". ${ }^{71}$ The seminal statement of this principle comes from L Schuler AG $v$ Wickman Machine Tool Sales Ltd: ${ }^{72}$

66 Chartbrook Ltd v Persimmon Homes Ltd, above n 63, at [21] and [25].

67 Chartbrook Ltd v Persimmon Homes Ltd, ibid at [25]; see also Ewan McKendrick Contract Law: Text, Cases and Materials, above n 3, at 388; Pink Floyd Music Ltd v EMI Records Ltd [2010] EWCA Civ 1429, 1 WLR 770 at [21].

68 HG Beale (ed) Chitty on Contracts (30th ed, Sweet \& Maxwell, London, 2004) at 852; Credential Bath Street Ltd v Venture Investment Placement Ltd [2007] CSOH 208, [2008] Hous LR 2 at [24].

69 Ing Bank NVv Ros Roca SA [2011] EWCA Civ 353, [2012] 1 WLR 472 at [110].

70 David McLauchlan "A Construction Conundrum", above n 48.

71 Christopher Staughton "How Do the Courts Interpret Commercial Contracts?", above n 2, at 308. See also Charter Reinsurance Co Ltd v Fagan [1997] AC 313 (HL) at 338. McMeel enthusiastically describes this consequential analysis as a "candidate for the most important principle of construction": "The Principles and 
The fact that a particular construction leads to a very unreasonable result must be a relevant consideration. The more unreasonable the result the more unlikely it is that the parties can have intended it, and if they do intend it the more necessary it is that they shall make that intention abundantly clear.

In other words, a reasonable person expressing their view as to the meaning of a document is entitled to compare the relative workability of competing interpretations because it gives effect to the logical perception that contracting parties are unlikely to have agreed to something absurd. ${ }^{73}$ It is this general impetus against unreasonable results that translates, in the commercial context, to a desire to reject unbusinesslike interpretations and prefer those that are consistent with commercial sense. ${ }^{74}$ Courts assume that parties are less likely to have intended uncommercial consequences. ${ }^{75}$ Therefore it is less likely that a reasonable person would decide the document conveys a meaning with those results.

The consequences of a particular interpretation may, like context, lead the court to the conclusion that the parties did not intend the ordinary meaning of the words and hence they have made a linguistic mistake. ${ }^{76}$ If the results of giving the words their natural meaning would "flout business common sense", this could indicate an intention that the parties "plainly could not have had" because "experienced commercial contractors do not intentionally make such bargains". ${ }^{77}$ However, whether or not an interpretation would have commercially nonsensical consequences is not a comprehensive test for departure from the ordinary meaning of the words. ${ }^{78}$ As explained above, what is necessary is that the document would convey a different meaning to the reasonable

Policies of Contractual Construction" in Andrew Burrows and Edwin Peel (eds) Contract Terms (eds), above $n 1,27$ at 43 .

72 L Schuler AG v Wickman Machine Tool Sales Ltd [1974] AC 235 (HL) at 251.

73 Ewen McKendrick "The Interpretation of Contracts: Lord Hoffmann's Restatement", above n 58, at 161; see also Kazakstan Wool Processors (Europe) Ltd v Nederlandsche Credietverzekering Maatschappij NV [2010] EWCA Civ 41, [2011] QB 8 at [49].

74 MP Furmston and JN Adams (eds) The Law of Contract, above n 49, at 673; Kim Lewison The Interpretation of Contracts (4th ed, Sweet \& Maxwell, London, 2007) at 293.

75 See Vector Gas Ltd v Bay of Plenty Energy Ltd [2010] NZSC 5, [2010] 2 NZLR 444 at [123] per Wilson J.

76 Lord Hoffmann explained as much in his fifth principle in Investors Compensation Scheme Ltd v West Bromwich Building Society, above n 59, at 913.

77 BP Exploration Operating Co Ltd v Kvaerner Oilfield Products Ltd [2004] EWHC 999 (Comm), [2004] 2 All ER (Comm) 266 at [93].

78 If it were, McLauchlan points out, the Investors Compensation decision itself would "almost certainly" have been decided differently: David McLauchlan "Contract Interpretation in the Supreme Court - Easy Case, Hard Law?" (2010) 16 NZBLQ 229 at 263-264. Lord Clarke confirmed as much in Rainy Sky SA v Kookmin Bank, above n 63, at [20]. 
person positioned as the parties were. ${ }^{79}$ The reasonable person could conceivably be persuaded to that effect where the words' ordinary meaning is not wholly unbusinesslike, but merely less commercially sensible than the alternative. ${ }^{80}$ If a lack of commercially nonsensical results prevented a court departing from the natural meaning of the words, this would effectively be a retreat to the long-abandoned literal approach that words should be given their plain meaning unless that would lead to absurd results. ${ }^{81}$

This same logic applies in cases where the contest is not between the ordinary meaning of the words and one that is less grammatically accurate. The court may be engaged in choosing between two possible meanings of ambiguous words, or two unnatural meanings, or the language of the contract may be apt per se and the issue is what it encompasses. ${ }^{82}$ In these situations, a court can similarly reject an interpretation that flouts business common sense as one that the parties cannot have intended. ${ }^{83}$ If neither interpretation has consequences that are that unbusinesslike, a court is entitled to prefer a more commercially sensible interpretation as that which the parties are more likely to have intended. ${ }^{84}$ This avoids an artificial distinction between interpretations that result in "absurdity" and those that are merely "uncommercial". 85

79 This is essentially what the requirements explained above amount to: see text to nns 65 and 67.

80 This is especially likely if the alternative meaning is supported by contextual considerations, but it cannot conclusively be confined to such cases. However, if the only indication that the document would convey to a reasonable person a meaning other than the natural meaning of its words is its consequences, a high standard of uncommerciality may indeed be required to establish the "strong case" that is required to "persuade a court that something must have gone wrong with the language" (Chartbrook Ltd $v$ Persimmon Homes Ltd, above $\mathrm{n} \mathrm{63,} \mathrm{at} \mathrm{[15]).} \mathrm{But} \mathrm{even} \mathrm{in} \mathrm{these} \mathrm{cases,} \mathrm{all} \mathrm{that} \mathrm{is} \mathrm{required} \mathrm{is} \mathrm{for} \mathrm{a} \mathrm{reasonable} \mathrm{person} \mathrm{to} \mathrm{be} \mathrm{convinced}$ that it was that alternative meaning which the document would convey.

81 David McLauchlan "Contract Interpretation in the Supreme Court - Easy Case, Hard Law?", above n 78, at 263. Nevertheless, there is a concerning emerging judicial tendency to require commercially absurd consequences - or a result "so extreme as to suggest that it was unintended", before a court is prepared to give a contract a meaning other than the ordinary meaning of the words: Kookmin Bank v Rainy Sky SA [2010] EWCA Civ 582, [2010] 1 CLC 829 at [42]. In Western Export Services Inc v Jireh International Pty Ltd [2011] HCA 45 the High Court of Australia upheld the New South Wales Court of Appeal's decision to this effect: Jireh International Pty Ltd t/as Gloria Jean's Coffee v Western Exports Services Inc [2011] NSWCA 137 at [55]. Fortunately the United Kingdom Supreme Court rejected this line of reasoning in Rainy Sky SA v Kookmin Bank, above n 63, at [20]. See further David McLauchlan and Matthew Lees "Construction Controversy" (2011) 28 JCL 101 at 108-110.

82 Chen-Wishart suggests that under the contextual approach the courts "often have to choose between different reasonable meanings, and the factors affecting that choice go beyond purely linguistic ones": Mindy Chen-Wishart Contract Law, above n 3, at 441. See also SC Smith "Making Sense of Contracts" (1999) SLT 307 at 311.

83 Kookmin Bank v Rainy Sky SA, above n 82, at [19] per Sir Simon Tuckey (dissenting).

84 Rainy Sky SA v Kookmin Bank, above n 63, at [21] and [28]-[30]; Paul Morgan "The Construction of Leases and Other Documents" (1999) L \& T Review 88 at 89. As Smith observes, "it need only ever be said of a particular interpretation that it is better than its rival, not that it is the only one available": SC Smith 
This consequential analysis presupposes that courts can evaluate commercial likelihood. But judges' "instinctive appreciation of commercial likelihood" is not necessarily reliable. ${ }^{86}$ In Skanska Rashleigh Weatherfoil Ltd $v$ Somerfield Stores Ltd, Neuberger LJ was sufficiently humble to point out: 87

Judges are not always the most commercially-minded, let alone the most commercially experienced, of people, and should, I think, avoid arrogating to themselves overconfidently the role of arbiter of commercial reasonableness or likelihood.

Furthermore, judicial assessment of commercial likelihood risks the imposition of the courts' standard of reasonableness over the top of the parties' own perceptions of business common sense. As Lord Reed pointed out in Credential Bath Street Ltd $v$ Venture Investment Placement Ltd: ${ }^{88}$

It is also necessary to heed the warnings which have been given ... against excessive confidence that a judge's view as to what might be commercially sensible necessarily coincides with the views of those actually involved in commercial contracts.

Nevertheless, a court interprets from the position of the reasonable businessperson and is entitled to apply its standard of commercial likelihood. Yet, judicial opinion may diverge as to what constitutes objective business common sense in any given case. ${ }^{89}$ As Brownsword observes: ${ }^{90}$

Quite simply, the problem is that, in none of these cases does the particular context offer unequivocal standards of reasonableness to inform the reasonable person's understanding of the contractual

"Making Sense of Contracts", above n 82, at 311; see also Co-operative Wholesale Society Ltd v National Westminster Bank Plc [1995] 1 EGLR 97 (EWCA Civ) at 99.

85 In Jireh International Pty Ltd t/as Gloria Jean's Coffee $v$ Western Exports Services Inc, the New South Wales Court of Appeal relied upon this distinction as a reason for refusing to depart from the ordinary meaning of the contract: above n 81, at [64]. However, Lord Mustill has warned that, "where there is no obvious absurdity, and simply assertions by either side that its own interpretation yields the more sensible result, there is room for error": Torvald Klaveness A/S v Arni Maritime Corp [1994] 1 WLR 1465 (HL) at 1473.

86 Sinochem International Oil (London) Co Ltd v Mobil Sales \& Supply Corp [2000] All ER (Comm) 474 (EWCA Civ) at [24].

87 Skanska Rashleigh Weatherfoil Ltd v Somerfield Stores Ltd [2006] EWCA Civ 1732, [2007] CILL 2449 at [22].

88 Credential Bath Street Ltd v Venture Investment Placement Ltd, above n 68, at [24] (emphasis added).

89 Maggbury Pty $v$ Hafele Australia [2001] HCA 70, (2001) 210 CLR 181 at 198; see also PS Davies "Interpreting Commercial Contracts: Back to the Top", above n 54, at 187. It is not uncommon for judicial opinion to be divided on the issue. One need look no further than the recent United Kingdom Court of Appeal and Supreme Court decisions in Kookmin Bank, above nn 63 and 81.

90 Roger Brownsword Contract Law: Themes for the Twenty-First Century (2nd ed, Oxford University Press, Oxford, 2006) at 162. 
documents. What we find in these cases is that the context is peppered with references to what would be ridiculous, unrealistic, nonsensical, and inherently unattractive and the like in order to induce a particular resolution of the question. Clearly, there is a danger that contextualism becomes another name for construing the contract until one arrives at the result one wants.

Imposing equivocal judicial standards of business common sense risks defeating, rather than protecting, the parties' reasonable expectations because "where judges rely on their own standards of reasonableness, the parties are no longer in control of their rights and obligations". ${ }^{91}$ It is here that a court engaging in commercial interpretation risks remaking the parties' bargain in accordance with its own opinion of what would have been more, or most, businesslike or commercially sensible.

\section{TWO PRINCIPLED LIMITS}

The dangers highlighted above illustrate the necessity of a principled approach to how judges conduct assessments of commercial likelihood and what kind of consequences can legitimately be considered more or less businesslike. If Brownsword's conclusion is accepted, we cannot safely rely upon a comprehensive survey of case law for authoritative direction on these questions. More useful guidance can be found in considering the rationale for the consequential analysis, from which can be derived two necessary limits to this aspect of commercial interpretation. For as Lord Steyn observes: "[t]he modern view is that the reason for a rule is important. The rule ought to apply where reason requires it, and no further". ${ }^{92}$

First, if the purpose of comparing the consequences of rival interpretations is to identify which meaning the parties are more or less likely to have intended, then the results of competing interpretations, and their consistency with business common sense, must be evaluated at the point when those intentions crystallised - when the contract was formed. ${ }^{93}$ Consequences that the parties were not, and could not reasonably have been, aware of at that time cannot have influenced their intentions. ${ }^{94}$ They are irrelevant to interpretation: the document is interpreted from the standpoint of the notional reasonable person positioned as the actual parties were and with the knowledge reasonably available to them at the time of the contract. ${ }^{95}$

91 Ibid at 106.

92 Johan Steyn "Contract Law: Fulfilling the Reasonable Expectations of Honest Men", above n 56, at 433.

93 Robert Bradgate "Contracts, Contract Law and Reasonable Expectations" in Sarah Worthington (ed) Commercial Law and Commercial Practice, above n 58, 651 at 658. The words of the contract must be given the meaning they bore at that date. See Total Gas Marketing Ltd v Arco British Ltd [1998] 2 Lloyd's Rep 209 (HL) at 221 and McLaren v Waikato Regional Council [1993] 1 NZLR 710 (HC) at 731.

94 Kim Lewison The Interpretation of Contracts, above n 74, at 108.

95 Johan Steyn "The Intractable Problem of the Interpretation of Legal Texts" in Sarah Worthington (ed) Commercial Law and Commercial Practice), above n 58, 123 at 124; see Lord Hoffmann's second principle in Investors Compensation Scheme Ltd v West Bromwich Building Society, above n 59, at 912; Reardon 
Therefore, a judge cannot apply the benefits of hindsight in a way that would presume the parties to have the "foresight of a prophet". ${ }^{96}$ Otherwise unanticipated consequences could alter the meaning of a document so that "a contract meant one thing the day it was signed, but by reason of subsequent events meant something different a month or a year later". ${ }^{97}$ Instead, if the consequences of a bargain have been fundamentally changed by subsequent events, the common law's solution is to terminate the contract on the ground of frustration. ${ }^{98}$ This releases the parties from the bargain, leaving them free to renegotiate for themselves in the light of the new circumstances. But it is for the parties to do so. What bargain they would have made, and might now make, in light of the circumstances that have arisen is a matter of speculation and guesswork inappropriate for the courts. ${ }^{99}$ The proper question is: which bargain is it more likely that the parties did make, in light of the consequences apparent at the time?

A second limitation is that, if the result of competing interpretations indicates which meaning the parties are more or less likely to have intended, then the consequences that courts consider to be more or less businesslike for that purpose should reflect upon the intentions of both parties. Unfortunately often an interpretation that seems rational and sensible to one party will seem commercially absurd to the other. As Spigelman J, writing extrajudicially, explains: ${ }^{100}$

The only difficulty is that, at least when the matter comes to the level of litigation, each party remains convinced that "a business-like" interpretation or "business commonsense" happens to coincide with its own commercial interests.

Nevertheless, courts must be sensitive to the position of both parties and consider the consequences from both standpoints. ${ }^{101}$ Ensuring that the consequences a court considers to be uncommercial reflect upon both parties' intentions largely avoids the danger of a court rescuing one

Smith Line Ltd v Yngvar Hansen-Tangen [1976] 1 WLR 989 (HL) at 997; Prenn v Simmonds [1971] 1 WLR 1381 (HL) at 1385.

96 British Movietonews Ltd v London and District Cinemas Ltd [1952] AC 166 (HL) at 183.

97 Whitworth St Estates v James Miller [1970] AC 583 (HL) at 603.

98 John Cartwright Contract Law: An Introduction to the English Law of Contract for the Civil Lawyer (Hart Publishing, Portland, 2007) at 244.

99 Kookmin Bank $v$ Rainy Sky SA, above n 81, at [42]; Bromarin AB v IMD Investments Ltd (1999) STC 301 (CA) per Chadwick LJ; see also Cassons v Ostley PJ Ltd [2001] EWCA Civ 1013, 85 Con LR 18 at [28][30].

100 JJ Spigelman "From Text to Context: Contemporary Contractual Interpretation" (2007) 81 ALJ 322 at 330.

101 Credential Bath Street Ltd v Venture Investment Placement Ltd, above n 68, at [25]. 
party from a bad bargain: the results avoided are more likely to be inconvenient or absurd to both parties. ${ }^{102}$

\section{ILLUSTRATING THESE LIMITS IN PRACTICE}

If a court adheres to these two limiting principles, a consequential analysis is more likely to serve its purpose of giving effect to the parties' intentions and expectations. This correspondingly mitigates the risk of a court remaking a contract in accordance with its own view of what bargain it would have been more sensible for the parties to have made. Several examples can illustrate what kind of consequences reflect upon both parties' intentions at the time the contract was formed, so that a court may legitimately consider them to be less businesslike. ${ }^{103}$

\section{A Examples of Uncommercial Results}

In L Schuler AG $v$ Wickman Machine Tool Sales Ltd, the House of Lords rejected an interpretation that gave Schuler the right to terminate the contract for any breach, however trivial, of the "condition" that Wickman must send one of two specific representatives to visit six different customers at least once every week to solicit orders for the sale of Schuler's products. ${ }^{104}$ This would amount to 1,400 visits over the duration of the agreement. The Court decided that neither party could have intended this meaning because compliance with that condition would be impossible if, during any particular week, both representatives were ill, or one of the customer firms told Wickman that they could not receive a representative. ${ }^{105}$ Breach of the term would be nearly inevitable. ${ }^{106}$ The assumption was that both parties more likely intended an interpretation that made the contract effective, rather than based upon unbusinesslike contingencies. ${ }^{107}$

102 However, courts should nevertheless be aware that sometimes parties do agree to contracts that are unusual or commercially inconvenient for both parties. As Catherine Mitchell points out, "there is no law that says contracts have to be reasonable": Interpretation of Contracts: Current Controversies in the Law (RoutledgeCavendish, London, 2007) at 94.

103 For present purposes, these cases are useful illustrations not necessarily because of the extent to which the consequences were unbusinesslike (see above $n$ 78) but for the kinds of consequences that they illustrate will be uncommercial. And in this regard they are not an exhaustive list. It would be impossible to compile one.

104 L Schuler AG v Wickman Machine Tool Sales Ltd, above n 72.

105 At 251 .

106 In other words, Lord Reid perceived an inevitable probability that "in a few cases out of the 1,400 required visits a visit as stipulated would be impossible", ibid; see also the analysis of Lord Morris, ibid at 258.

107 This uncommercial result persuaded the Court to give some alternative meaning to the word "condition". They were also influenced in the decision to do so by the inclusion of a term in the contract that gave the parties a conditional right to terminate for "material breach" of any term. The House of Lords decided that "condition" indicated that any breach would constitute a material breach for the purposes of that other clause. 
A similar issue arose in Antaios Cia Naviera SA v Salen Rederierna AB: whether a term that "on any breach of this Charter Party, the Owners shall be at liberty to withdraw the vessel from the service of the Charterers" referred to any breach or any repudiatory breach. ${ }^{108}$ The arbitrators had rejected the owners' construction because it was "wholly unreasonable, totally uncommercial and in total contradiction to the whole purpose of the NYPE time charter form". ${ }^{109}$ Although deprecating the label of "purposive interpretation", Lord Diplock accepted this reasoning and indicated that this kind of result "flouts business common sense". ${ }^{110}$ This illustrates that an interpretation that frustrates the contractual purpose can legitimately be considered unbusinesslike. It is certainly fair to assume that both parties entered the contract in order to further their goals. ${ }^{111}$ However, a court must be careful to identify the common goals of both parties. ${ }^{112}$

One final example is found in Chartbrook Ltd v Persimmon Homes Ltd. ${ }^{113}$ Lord Hoffmann rejected the interpretation accepted by the lower courts because its "striking feature" was that it made the structure and language of the contract "appear arbitrary and irrational" when it was possible for the scheme to work in a rational way. ${ }^{114}$ In other words, the judges thought it fair to assume that both parties were more likely to have intended a contractual scheme that was logical

108 Antaios Cia Naviera SA v Salen Rederierna AB [1985] AC 19 (HL).

109 At 201.

110 Ibid. It was here that Lord Diplock made his observation that:

... if detailed semantic and syntactical analysis of words in a commercial contract is going to lead to a conclusion that flouts business common sense, it must be made to yield to business common sense.

While this continues to be frequently cited, it is perhaps no longer as relevant. As explained above, a "detailed semantic and syntactical analysis" is no longer the starting point, and courts are no longer as concerned with the flouting business common sense threshold.

111 Nicole Kornet Contract Interpretation and Gap Filling: Comparative and Theoretical Perspectives (Intersentia [Maastricht] METRO, Antwerp, 2006) at 170. That this reflects upon the intentions of the parties at the time the contract was entered into is supported by the fact that some judges consider purpose to be part of the admissible background. See Reardon Smith Line Ltd v Yngvar Hansen-Tangen, above n 95, at 995:

In a commercial contract it is certainly right that the court should know the commercial purpose of the contract and this in turn presupposes knowledge of the genesis of the transaction, the background, the context, the market in which the parties are operating.

112 Bank of Nova Scotia v Hellenic Mutual War Risks [1990] QB 818 (CA) at 870; Gerard McMeel "The Rise of Commercial Construction in Contract Law", above n 50, at 390. Lord Wilberforce also recognised these difficulties in Prenn v Simmonds, above n 95, at 1385.

113 Chartbrook Ltd v Persimmon Homes Ltd, above n 63.

114 At [20] 
and workable rather than internally inconsistent. ${ }^{115}$ While time and circumstances may test the flaws of a contract, this unbusinesslike error had existed at the time the contract was formed. ${ }^{116}$

\section{B A Result That Is Not Uncommercial}

There is also one important result that a court cannot safely assume to be uncommercial for the purposes of legitimate contract interpretation. That an interpretation results in a bad bargain for one party is conceptually different from saying that it is unworkable or unbusinesslike. ${ }^{117}$ And in Chartbrook, Lord Hoffmann gave a clear indication that "the fact that a contract may appear to be unduly favourable to one of the parties is not a sufficient reason for supposing that it does not mean what it says". ${ }^{118}$ In other words, a disadvantageous bargain for one party is not a consequence that flouts business common sense and that the parties cannot have intended. ${ }^{119}$ Nor is it a less commercially sensible result that the parties are less likely to have intended.

This must be correct. As unqualified as judges may be to express their opinions as to commercial likelihood, they are even more poorly positioned to decide whether or not a bargain is fair. The common law has traditionally refused to inquire into adequacy of consideration out of recognition that value is inherently subjective. ${ }^{120}$ Even if the equality of an exchange could be objectively judged, courts are ill-informed to evaluate it properly: ${ }^{121}$

115 Lord Walker described this result not only "fairly surprising" but "totally incredible" when considered within the contractual scheme (ibid at [88]). However, the judges were not indicating that this level of absurdity was required before the court could depart from the ordinary meaning of the words. See above $\mathrm{n}$ 78; see also David McLauchlan "Contract Interpretation in the Supreme Court - Easy Case, Hard Law?", above n 78, at 263. A similar assumption was made in Sinochem International Oil (London) Co Ltd v Mobil Sales \& Supply Corp, above n 86, at [16] where a majority of the Court of Appeal thought it unlikely the parties had agreed to a "haphazard" scheme.

116 Ing Bank NVv Ros Roca SA, above n 69, at [83] per Rix LJ.

117 City Wall Properties (Scotland) Ltd v Pearl Assurance Plc 2004 SC 214 (OH) at [25].

118 Chartbrook Ltd v Persimmon Homes Ltd, above n 63, at [13]. In Chartbrook, the amount payable, if the contract was interpreted as Persimmon contended, was approximately $£ 900,000$. According to Chartbrook's interpretation the amount payable under the contract was almost $£ 4.5$ million.

119 Gerard McMeel Construction of Contracts: Interpretation, Implication and Rectification above n 61, at [1.59]:

... there is no general principle of construction in English law that judges are equipped with a general power or discretion to override the clearly expressed intentions of the parties on the basis that the result contended for is unfair, unreasonable, or contrary to good faith ...

120 See for example Bolton v Madden (1873) LR 9 QB 55 per Blackburn J. As Chen-Wishart describes it, "fairness lies in the eyes of the beholder": Mindy Chen-Wishart Contract Law, above n 3, at 15.

121 Jumbo King Ltd v Faithful Properties Ltd, above n 65, at [52]; Chartbrook Ltd v Persimmon Homes Ltd, above n 63, at [20]. 
The court is not privy to the negotiation of the agreement - evidence of such negotiations is inadmissible

- and has no way of knowing whether a clause which appears to have an onerous effect was a quid pro quo for some other concession.

Nor do courts understand "the commercial and other pressures which may have dictated the balance of interests which the contract strikes". ${ }^{122}$

Furthermore, even where a bargain is so glaringly one-sided that an objective court of interpretation cannot deny it, it cannot be assumed that neither party to a contract is likely to have intended that consequence. ${ }^{123}$ From the benefiting party's point of view, an unduly favourable bargain is a perfectly commercially sensible result. Besides, there is no guarantee that the disadvantaged party did not intend a bargain that, in effect, was "hopelessly uneconomic". ${ }^{124}$ Presumably no party enters a contract unless they believe themselves to be consequently better off. ${ }^{125}$ That a party was mistaken as to the effect of the bargain does not mean that they did not, at the time, intend it. Courts must always be alert to the possibility that one party has simply made a bad bargain and remember that it is not the courts' role to rescue them. ${ }^{126}$ Freedom of contract requires that parties should be free to make even very unwise bargains.

One final reason why it is wrong to assume that neither party is likely to have intended a bargain that appears disastrously unfavourable to one party is that New Zealand law places no general obligation on parties to a commercial contract to protect each other's interests. ${ }^{127}$ Rather than notions of good faith, caveat emptor is a basic facet of the common law of contract: each party is entitled to pursue their own interests and assume that the other party is protecting their own interests

122 Kookmin Bank v Rainy Sky SA, above n 81, at [42]. Hugh Collins provides a useful discussion of this point in Regulating Contracts (Oxford University Press, Oxford, 2005) at 136.

123 Blanchard J arguably fell into this trap in Vector Gas Ltd v Bay of Plenty Energy Ltd, above n 75, at [8] and [10]; see a discussion of the case in David McLauchlan "A Construction Conundrum", above n 48.

124 See for example Board of Trustees of the National Provident Fund v Brierley Investments Ltd [1991] 1 NZLR 1 (PC), and Ing Bank NV v Ros Roca SA, above n 69, at [24] where "The mistake was not in the language, but in failing to anticipate its consequences".

125 Nicole Kornet Contract Interpretation and Gap Filling: Comparative and Theoretical Perspectives, above n 111, at 325; PS Atiyah and Stephen A Smith Atiyah's Introduction to the Law of Contract (6th ed, Oxford University Press, Oxford, 2006) at 3.

126 Vector Gas Ltd v Bay of Plenty Energy Ltd, above n 75, at [126].

127 The qualifications to this are discussed below, see nn 139 and 140. 
too. ${ }^{128}$ Any unfairness is vindicated through invalidating doctrines such as unconscionable bargain or undue influence, not interpretation. ${ }^{129}$

\section{A Difficult Distinction}

It would therefore be improper for courts to assume in every case that neither party to a commercial contract would have intended a bargain that is unduly favourable to one party. Inequality of exchange does not fall within the scope of consequences that a court can legitimately consider to be less businesslike. However, in some circumstances, the distinction between the impermissible consideration of fairness and the permissible consideration of commercial workability may be difficult to draw.

One difficulty is that a consequence that one judge sees as reflecting upon the fairness of the exchange of the bargain may be perceived by another to be a matter of commerciality. Deutsche Genossenschaftsbank $v$ Burnhope, where the House of Lords was asked to ascertain the scope of the bank's insurance policy, provides an example. ${ }^{130}$ In his dissent, Lord Steyn thought that the distinction between theft committed by a person in the bank and theft committed by a person sitting in a taxi outside the bank through an innocent agent inside was totally "uncommercial". ${ }^{131}$ However, Lord Lloyd (in the majority) disagreed: ${ }^{132}$

No doubt the bank could, by paying an increased premium, have covered themselves against theft by electronic transfer. But equally they may have decided, for sound commercial reasons, to pay a lower premium, and limit the cover to thefts by persons actually present on the premises.

This reflects the nearly unavoidable reality that judges are influenced by normative considerations, and the possibility that these may both inform and be concealed behind concerns for unbusinesslike results.

A second difficulty is that, even where it is clear that the consequence pertains to the equality of the exchange, there may be cases where "the commercial advantage would be so great that it moves

128 Johan Steyn "The Role of Good Faith and Fair Dealing in Contract Law: A Hair-Shirt Philosophy?" (1991) 6 Denning LJ 131 at 136; Ing Bank NVv Ros Roca SA, above n 69, at [92]; Kookmin Bank v Rainy Sky SA, above $n$ 81, at [41].

129 See Mindy Chen-Wishart Contract Law, above n 3, at 13.

130 Deutsche Genossenschaftsbank v Burnhope [1995] 1 WLR 1580 (HL).

131 At 1589.

132 At 1585. McMeel has criticised Lord Lloyd's approach on the grounds that he was "scrutinizing the adequacy of consideration, and/or fairness of the bargain; neither is permissible": Gerard McMeel "The Rise of Commercial Construction in Contract Law", above n 50, at 391. 
the case into the sphere of irrationality and arbitrariness". ${ }^{133}$ How does one distinguish between an unduly favourable contract and a commercially absurd result?

The solution cannot be that an exceedingly favourable bargain will be unbusinesslike where there is no apparent rationale for the benefit. ${ }^{134}$ The court is ill-equipped to determine whether or not there has been compromise or quid pro quo. Regardless, the party who stands to enjoy a good bargain should not have to prove they have earned it by some other concession. Conversely, if there is a reasonable explanation or objectively apparent concession, this may be a strong indication that the bargain was not so unfavourable as to be uncommercial.

Nor can an unfavourable consequence be unbusinesslike if the surprising extent of the commercial advantage has only arisen after the contract was formed. It is perhaps more likely that supervening circumstances will alter the balance of a bargain than that they will change the operation of the contractual scheme. Therefore, courts should be especially vigilant in these cases to comply with the first of the principled limits explained above: that the consequences of the rival interpretations must be considered from the standpoint of a reasonable person in the same circumstances as the parties at the time the contract was formed. Contracts involve an allocation of risks between parties and that the eventuation of a particular risk, whether foreseen or unexpected, upsets the balance of the contract is not an excuse for a court to readjust the bargain or reallocate the risks. ${ }^{135}$ For this reason, Chadwick LJ was right to conclude that: ${ }^{136}$

The fact that a party gets less than he may have hoped for in a bargain does not mean that the bargain produces "a nonsense"; it means only that it produces a less advantageous result [than] the party might have hoped to obtain.

However, the fact that the inequality of a bargain was startling at the time the contract was formed cannot suffice to render it an unbusinesslike result. Perhaps the greatest guidance can be

133 Bashir v Ali [2011] EWCA Civ 707, [2011] 2 P \& CR 12 at [40]. It was unnecessary to answer the question in that case.

134 Although his reasoning was erroneous on other grounds, Patten LJ expressed this point nicely in Kookmin Bank v Rainy Sky SA, above n 81, at [51]:

... merely to say that no credible commercial reason has been advanced for the limited scope of the bond does, in my view, put us in real danger of substituting our own judgment of the commerciality of the transaction for that of those who were actually party to it.

To clarify, the author here uses "rationale" in the sense of an apparent concession or compromise, rather than to refer to the purpose of the contract.

135 See for example Lim v McLean [1997] 1 NZLR 641 (PC) in which the parties had agreed to share half of a fishing quota of not less than 447 tonnes of Orange Roughy. When the quota that was subsequently allocated far exceeded that, the Privy Council decided this was a risk that the owner had accepted and he was nevertheless obliged to transfer half of the full quota that was, in fact, allocated.

136 Megaro v Di Popolo Hotels Ltd, above n 52, at [23]. 
found in the second limit derived from the rationale for a consequential analysis: there must be some aspect of the unfavourable bargain that causes it to reflect upon both parties' intentions before it will move into the sphere of an unbusinesslike result. This could conceivably occur when the benefit would arise in a manner that neither party is likely to have intended, such as through perversion of the contractual scheme. ${ }^{137}$ Or there may be situations where for one party to enjoy the advantage would frustrate the parties' common purpose. ${ }^{138}$

One final possibility is that it may be clear from the circumstances or the particular parties' relationship that they intended a cooperative rather than aggressive approach to negotiations, so as to displace the principle of caveat emptor. The courts' traditional reluctance to recognise the validity of express agreements to negotiate in good faith is perhaps weakening, ${ }^{139}$ and New Zealand courts have become more willing to imply a term requiring good faith into certain types of contract. ${ }^{140}$

It would be impossible to draw a determinative line between unfairness and commerciality. The greatest assistance is found in the two limiting principles, explained above, that ensure consequential considerations properly serve their purpose: an unduly favourable or exceedingly unfavourable result for one party will be an unbusinesslike consequence when it is evident that neither party is likely to have intended it at the time the contract was made. These constraints may mean it is rare for a court to conclude the line has been crossed. But that is entirely appropriate and a different thing altogether from saying it is impossible.

\section{RETURNING TO MULTI-LINK}

This discussion exposes the dangers of the windfall analysis in Multi-Link. A windfall cannot shed such decisive light on the parties' intentions as the United Kingdom Supreme Court Judges seem to think.

137 See New Zealand Sports Merchandising Ltd v DSL Logistics Ltd HC Auckland Civ-2009-404-005548, 16 October 2009. In that case Priestley J decided the opposite - that the parties must have intended for the benefit to arise, because the alternative interpretation would leave the contract vulnerable to perversion by either party so that they could receive a "windfall".

138 This was one of the reasons underlying the Court of Appeal decision in Yoshimoto v Canterbury Golf International [2001] 1 NZLR 523 (CA) at [39]. That the Privy Council disagreed and overturned that decision does not totally negate the possibility that there may be cases where this conclusion could legitimately be reached.

139 See John Burrows, Jeremy Finn and Stephen Todd Law of Contract in New Zealand (3rd ed, LexisNexis NZ, Wellington, 2007) at 177-178. However, in Wellington City Council $v$ Body Corporate 51702 (Wellington) [2002] 3 NZLR 486 (CA) the Court of Appeal followed Walford v Miles [1992] 2 AC 128 (HL) and refused to recognise the validity of an agreement to negotiate in good faith because it could not be given any sufficiently certain content.

140 See John Burrows, Jeremy Finn and Stephen Todd Law of Contract in New Zealand, ibid. 
First, although the term "windfall" has rhetorical power, a windfall in the Multi-Link sense is an inherently troublesome concept. It is unclear what size advantage will constitute a windfall, or how unexpected that benefit must be. Furthermore, the windfall depends upon a judicial decision as to where this unexpected benefit lies. In Multi-Link, it was also arguably a windfall for the Council to be able to sell the land for a price significantly higher than was probably contemplated at the time they entered the lease. And finally, Lord Clarke's description of the windfall as "unwarranted" is problematic, by which he presumably means the benefit was unjustified on the terms of the contract. This begs the very question the Court was asked to answer: whether or not Multi-Link was contractually entitled to the windfall.

Secondly, the windfall to Multi-Link was not a consequence that existed at the time the lease was entered into and it therefore cannot have influenced the parties' intentions. It was caused by unanticipated circumstances (the planning changes) that arose after the formation of the contract. Properly considered, from the standpoint of a reasonable person in the position of the parties at the time the lease was entered into, Multi-Link's interpretation did not necessarily result in any exceptional commercial advantage to the tenants. Baroness Hale made insightful observations on this point (although unfortunately she considered them to be "by the by"):141

I do not regard the tenants' position as quite as fanciful as others might. Local authorities are not commercial organisations. They are there to serve the local population, not to make money. In 1999, it appears that no-one was thinking about the potential for residential development. The council, no doubt conscious of their responsibility to provide facilities for healthy recreation for the inhabitants of Cumbernauld, wanted a pay and play golf course which all could enjoy. The tenants were prepared to take the commercial risk of developing the land as a golf course. The council were happy to tie up the land for that purpose for 50 years. On the Lord Ordinary's view of the matter, if the option were exercised they would not only have had the course built but would also have been paid for it. Had it not been for the possibilities opened up by the regional development plan, that might have seemed a good deal to them.

Lord Glennie reached a similar conclusion: ${ }^{142}$

... the [Council] might reasonably have thought, in 1999 or 2000, that granting an option to purchase at a price referable to the use of the subjects as a golf course provided the best opportunity of procuring the lease on the terms and at the rent on which it was procured.

Even if, at the time the lease was entered into, there was a reasonably foreseeable risk that hope value would arise, Multi-Link's interpretation did not necessarily result in an unduly favourable

141 Multi-Link Leisure Developments Ltd v North Lanarkshire Council (UKSC), above n 5, at [41] (emphasis added).

142 Multi-Link Leisure Developments Ltd v North Lanarkshire Council (OH), above n 6, at [12] (emphasis added). 
bargain to the tenants. The Council could have decided that to exclude any hope value was a calculated business risk to take in return for the concession by Multi-Link to pay twice for the golf course (as, according to the assumptions and disregards, the land was to be valued as developed). That significant hope value subsequently arose cannot have affected the parties intentions at the time the lease was entered into and certainly did not give the United Kingdom Supreme Court license to reallocate that risk.

Furthermore, even assuming, contrary to the evidence, that the Multi-Link windfall was a consequence that existed at the time the parties entered the lease, it did not constitute an uncommercial result or an outcome that flouted business common sense. That is, there was nothing to suggest that a windfall to Multi-Link was a result that neither party was likely to have intended. Almost certainly, Multi-Link intended to secure the best bargain possible, and to exclude the hope value would have seemed entirely commercially sensible. As Lord Hope said, they were "in business to make money". ${ }^{143}$ Nor, if the Council had agreed to exclude the hope value in return for Multi-Link's undertaking to pay twice for the golf course, could it be said there was no possible justification for the substantial commercial benefit to Multi-Link. Therefore even if it were relevant what bargain the parties would have made in light of the windfall, it cannot be said with any confidence that they would more likely have agreed for the option price to include any hope value. Furthermore, the windfall did not change how the option contract worked together, or achieved its purpose. The option could still have been exercised, and the option price determined, even if the hope value was excluded. ${ }^{144}$ There is nothing to suggest that the windfall was anything other than an exceedingly favourable bargain for Multi-Link.

The Multi-Link case therefore provides a neat illustration of an illegitimate application of the modern commercial approach to contract interpretation. The windfall was neither a consequence that existed at the time the parties entered the lease, or a result that both parties were unlikely to have intended. The United Kingdom Supreme Court's analysis therefore contravened both of the limiting principles that keep the consequential analysis within proper bounds. Multi-Link illustrates how failing to adhere to those limits can lead a court into impermissible territory. By intervening on the ground that supervening events had made the bargain more favourable to one party the Court arguably, under the guise of interpretation, rewrote the contract to rescue the Council from a perceived bad bargain. And if the United Kingdom Supreme Court did so, this was not only illegitimate, but also conferred a windfall upon the Council. For as Hurt explains, "judicial

143 Multi-Link Leisure Developments Ltd v North Lanarkshire Council (UKSC), above n 5, at [22].

144 Despite Lord Rodger's opinion that to exclude the hope value would be an unusual approach to determining full market value, he admits that "no doubt [a valuer] would be able to assess what someone wanting to buy a golf course would pay for this course in this area": ibid at [34]. 
intervention that necessarily disrupts what the parties bargained for ex-ante, then creates an arguable windfall for the person receiving relief from a bad bargain". ${ }^{145}$

\section{CONCLUSION}

To say the Supreme Court's reasoning was unsafe is not to say that the Court made the wrong decision in Multi-Link. It was a finely balanced issue. Perhaps the Judges are therefore spared the criticism of rewriting the parties' bargain in this case. However, the significance of their reasoning should not be overlooked.

First, the Multi-Link decision illustrates the fine line between preferring interpretations that have commercially sensible results, and making the contract for the parties that, in the court's own view, would have been more commercially sensible. When the former becomes the latter, the raison d'être for commercial interpretation is compromised, for the parties' intentions are undermined rather than given greater effect. Nothing is further from facilitating the transactions of commercial men than remaking them, or ceasing to oil the wheels of commerce and beginning to steer them. ${ }^{146}$ These are illegitimate roles for a court resolving an interpretation dispute.

Secondly, the Supreme Court went beyond preferring the interpretation that did not result in a windfall. Lords Hope and Rodger and Baroness Hale all indicated that, if Multi-Link had provided expressly for their advantageous bargain, the Court would have given effect to their interpretation. ${ }^{147}$ This overlooks the fact that, if neither party anticipated the land having any hope value, they could not possibly be expected to expressly exclude it. But more importantly, it reveals an attitude that requires a contracting party to spell out in the plainest language the benefits of a bargain before they are entitled to them. This is a retreat from the modern, common sense approach that asks only: what is the meaning the document would convey to a reasonable third person, situated as the parties were? If Multi-Link's interpretation was that meaning, they were entitled to rely upon it rather than risk losing the bargain by insisting upon a more express term to the same effect.

Just as the judges' willingness to avoid a disadvantageous result for the Council shows a concern for the fairness of the bargain, Lewison has pointed out that often when courts refuse to give a

145 Christine Hurt "The Windfall Myth" (2010) 8 Geo JL \& Pub Policy 339 at 341.

146 Compare with Sir Robert Goff's opinion in Robert Goff "Commercial Contracts and the Commercial Court", above $\mathrm{n}$, at 391, that judges':

... only desire is to give sensible commercial effect to the transaction. We are there to help businessmen, not to hinder them: we are there to give effect to their transactions, not to frustrate them: we are there to oil the wheels of commerce, not to put a spanner in the works, or even grit in the oil

147 See Multi-Link Leisure Developments Ltd v North Lanarkshire Council (UKSC), above n 5, at [16], [36] and [43] respectively. 
document a certain meaning in the absence of clear words, this is generally because "the effect of the document is unfair". ${ }^{148}$ The United Kingdom Supreme Court's reliance upon notions of fairness as persuasive reasons to reject Multi-Link's interpretation perhaps goes beyond the extent to which normative concerns inevitably inform judicial instincts. To attribute such decisive weight to these concerns compromises the traditionally prioritised values of freedom, certainty and sanctity of contract. It overlooks the reality that certainty is the most important ingredient of fairness in commercial law. ${ }^{149}$ If this approach is followed, it could be seen as another step in the trend identified many years ago by Lord Wilberforce in National Carriers v Panalpina: ${ }^{150}$

I think that the movement of the law of contract is away from a rigid theory of autonomy towards the discovery - or I do not hesitate to say imposition - by the court of just solutions...

148 Kim Lewison The Interpretation of Contracts, above n 74, at 47-48.

149 Richard Calnan "Construction of Commercial Contracts: A Practitioner's Perspective", above n 1, at 20; See also David McLauchlan "The 'New' Law of Contract in New Zealand" (1992) NZ Recent L Rev 436; and Andrew Phang "Security of Contract and the Pursuit of Fairness", above n 55.

150 National Carriers v Panalpina [1981] AC 675 (HL) at 696. 
